\title{
Język wrażliwy na płeć w edukacji. Analiza wybranych dokumentów uniwersyteckich
}

\section{KEYWORDS}

gender sensitive language, feminine forms, linguistic androcentrism, language asymmetry in education

\begin{abstract}
Julia Sawicka, Język wrażliwy na płeć w edukacji. Analiza wybranych dokumentów uniwersyteckich [Gender-sensitive language in education. Analysis of selected university documents]. Kultura - Społeczeństwo - Edukacja nr 1(19) 2021, Poznań 2021, pp. 203-217, Adam Mickiewicz University Press. ISSN 2300-0422. DOI 10.14746/ kse.2021.19.14
\end{abstract}

The purpose of the article is to discuss issues related to the gender-sensitive language used in education, as well as how feminine forms function in Polish language. In particular, the documents analyzed are those used at Adam Mickiewicz University in Poznan. The basic question that underlies the discussion here refers to gender-specific asymmetry in language and its impact on shaping reality.

\section{Wprowadzenie}

„Język jest kodem i narzędziem, które jednocześnie opisuje świat, kształtuje wyobrażenia mówiących i słuchających oraz wartościuje" (Duda, 2016: 186). Nie ulega zatem wątpliwości, że ma on znaczny wpływ na niemal każdą sferę naszego życia, w tym także na postrzeganie własnej i cudzej płci. Relacje między płcią i językiem często bywają jednak nad wyraz skomplikowane i trudne do usystematyzowania czy ujęcia w sztywne ramy. W wielu językach na świecie, $w$ tym także $w$ języku polskim, już na pierwszy rzut oka widoczny jest nierówny obraz płci, co rzutuje na rzeczywistość społeczną, z jaką mamy do czynienia.

\footnotetext{
* ORCID: https://orcid.org/0000-0002-0498-8197.
} 
Emancypacja kobiet zapoczątkowała ogromne zmiany w życiu społecznym, jednak język zdaje się nie nadążać za tymi przeobrażeniami ogólnoświatowymi i nadal trzyma się świata androcentrycznego ${ }^{1}$. Dowodami na to są publikacje m.in. Karwatowskiej i Szpyry-Kozłowskiej (2005), Wtorkowskiej (2019) czy Łazińskiego (2006). Coraz głośniejszym echem odbijają się sugestie dotyczące równości płci również na polu językowym. $\mathrm{Z}$ zainteresowaniem przyglądałam się burzliwym dyskusjom na temat feminatywów, toczącym się w ostatnich latach. Ciekawość nie tylko specjalistów, ale również osób niezwiązanych z sektorem lingwistyki oraz dyskusje szeroko prowadzone w mediach skłoniły mnie do bliższego przyjrzenia się tej tematyce.

W artykule poruszyłam problematykę niejednakowego wizerunku kobiet i mężczyzn w języku polskim, ze szczególnym uwzględnieniem języka używanego w sferze edukacji. Postanowiłam również nieco bliżej przyjrzeć się treściom zawartym w wybranych dokumentach uniwersyteckich i poddać je analizie w kontekście płciowych asymetrii językowych.

\section{Paradygmat konstruktywizmu społecznego}

Epiktet w I w p.n.e. pisał: „Człowiek podlega nie rzeczom, ale poglądom na ich temat" (Skalski, 2015: 114). Myśl tę dziś można byłoby uznać za zgodną z teorią konstruktywizmu społecznego. Jako jedną z głównych tez konstruktywizmu uznaje się tę mówiącą, że w kulturę integralnie wpleciona jest wiedza o świecie, która z kolei determinowana jest społecznie. To jednostka w każdej chwili, poprzez swoją działalność, kreuje rzeczywistość, postrzegając ją tym samym poprzez pryzmat swoich doświadczeń i kultury, w jakiej żyje. Jednostka przypisuje swoim doświadczeniom określone znaczenia. Co z kolei przekłada się na to, że żaden człowiek nie jest w stanie zaobserwować obiektywnej rzeczywistości, odseparowanej od nadawanych jej ludzkich znaczeń i kontekstów (Zamojska, 2010). Fundamentalną rolę w tworzeniu i funkcjonowaniu świata społecznego spełnia język, a świat społeczny nie jawi się jako rzeczywistość zewnętrzna wobec ludzi zupełnie od nich niezależna i nieulegająca zmianom. Na konstrukcję świata składają się interakcje społeczne, które stopniowo utrwalają się w tradycji i dzięki socjalizacji. Tym samym konstruktywizm społeczny przyjmuje założenie, że język nie może być neutralnym narzędziem nazywania tego, co istnieje niezależnie od niego (Zamojska, 2010).

${ }^{1}$ Androcentryzm to wg S. Lipsitz-Bem „uprzywilejowanie męskiego doświadczenia jako neutralnej normy dla kultury i gatunku jako całości, a kobiet i kobiecego doświadczenia - jako naznaczonego płcią odchylenia od tej powszechnie obowiązującej normy” (Lipsitz-Bem, 2000). 
Pisząc o konstruktywizmie społecznym, nie sposób nie wspomnieć o hipotezie lingwistycznej Sapira-Whorfa, czyli prawie relatywizmu językowego. Hipoteza ta zakłada, że język, którego jednostka używa, w większym lub mniejszym stopniu determinuje jej sposób myślenia. Wszystkie elementy składające się na konkretny język, jak np. słownictwo, poziom narracji czy gramatyka powodują, że osoba się nim posługująca widzi świat w specyficzny, unikatowy i niepowtarzalny sposób (Sapir, 1978). Słabsza postać tej hipotezy - relatywizm językowy - zakłada, że język wpływa na myślenie, zachowanie i postępowanie w życiu społecznym, jednak jedynie w pewnym stopniu (Filipiak, 2008). Różnice między strukturami leksykalno-gramatycznymi w danym języku mają wpływ na różnice w interpretacji i percepcji świata. Skrajna postać hipotezy Sapira-Whorfa zakłada, że myślenie, postrzeganie świata jest całkowicie zdeterminowane przez język. Odpowiada ona twierdzeniu austriackiego filozofa Ludwiga Wittgensteina, który uważał, że: „Granice mego języka oznaczają granice mego świata” (Wittgenstein, 1970). Wittgenstein zakładał zatem, że to, czego język nie może nazwać lub opisać, nie istnieje w świecie jednostki (Kawiorski, 2014).

\section{Używanie języka w kontekście płci}

Pojęcie płci kształtowało się na przestrzeni wieków. Wcześniej sądzono, że cechy fizyczne osobników determinują przynależność do płci oraz roli społecznej i ogólnego stylu życia. Między kobietami i mężczyznami widoczne były pewne dysproporcje. Siła fizyczna była jedną z głównych cech niezbędnych przy przetrwaniu. Mężczyźni zazwyczaj byli bardziej postawni i silni, zajmowali się więc polowaniem i obroną członków społeczności. Kobiety natomiast były drobniejsze i, ze względu na brak w tamtych czasach wiedzy i środków w aspekcie kontroli rozrodczości, ciągle uwikłane w opiekę nad dziećmi lub ciążę. Ich rola w społeczeństwie prawdopodobnie sprowadzała się więc do wychowywania dzieci oraz prac związanych $z$ gospodarstwem domowym. Schematy te są na tyle utarte i zakorzenione w naszej historii, że współcześnie nadal obie płcie nie są sobie równe, mimo tego, że wyżej wymienione czynniki (w związku np. z rozwojem technologii) nie mają już tak kluczowego znaczenia. Obu płciom nadal przypisywane są odmienne role społeczne (Pikiel, 2000). Sam podział pracy na „męską” (np. hydraulik, informatyk, górnik, kierowca, inżynier) oraz „żeńską” (np. przedszkolanka, kosmetyczka) dodatkowo pogłębia asymetrię między płciami.

Poza płcią biologiczną istnieje także płeć społeczno-kulturowa. Odbiega ona od płci biologicznej, stanowi jej kulturową interpretację (Gontarczyk, 1995) two- 
rzoną dzięki jej stale podtrzymywanej społecznej inscenizacji (Buttler, Kurkowska, Satkiewicz, 2008). W koncepcji płci kulturowej ciało nie powinno nas definiować oraz ograniczać, gdyż płeć jest uwarunkowana nie biologicznie, a raczej społecznie i kulturowo.

Niektóre badania (np. Ziemińska, 2017) dowodzą istnienia większej liczby płci niż zwyczajowo się zakłada. Dodatkowo wcale nie muszą one być adekwatne do budowy anatomicznej osoby lub jej zdolności do wytwarzania konkretnego rodzaju komórek. Ziemińska (2017) wspomina o osobach interpłciowych, które można zdefiniować jako osoby, których ciało nie pasuje do binarnego podziału ludzi na mężczyzn i kobiety, gdyż mają niektóre organy płciowe męskie, a inne żeńskie (lub ich organy płciowe mają mieszany charakter). $Z$ tej definicji wynika istnienie trzeciej kategorii płciowej (innej niż modelowy podział na płeć męską i żeńską), która łączy w sobie cechy biologiczne i anatomiczne typowe dla obojga płci. Często osoby interpłciowe nie utożsamiają się z żadną z oficjalnych kategorii płci i lawirują gdzieś pomiędzy nimi.

Inną grupą, która wyłamuje się ze schematycznego podziału płci, są osoby z tożsamością niebinarną. Są to osoby, które nie identyfikują się ani jako kobieta, ani jako mężczyzna, lub identyfikują się jednocześnie jako kobieta i mężczyzna, lub też w jakimś okresie - jako kobieta, a w innym - jako mężczyzna, bądź też osoby te twierdzą, że nie mają żadnej tożsamości płciowej (Richards i in., 2016). W 2011 roku w Wielkiej Brytanii przeprowadzono ankietę, w której 0,4\% na ponad 10000 respondentów zidentyfikowało się jako osoby niebinarne (Glen, Hurrell, 2012).

Zjawisko podziału na płeć oraz związane z nią zagadnienia widoczne są także w języku, w którym: „(...) jak w lustrze, swoje odbicie znajdują dawne i obecne poglądy, postawy oraz przekonania jego użytkowników, z ich bogatym bagażem stereotypów kulturowo-społecznych (...)" (Karwatowska, Szpyra-Kozłowska, 2005). We współczesnej polszczyźnie wyraźnie zauważalny jest androcentryzm językowy, inaczej zwany seksizmem językowym (Karwatowska, Szpyra-Kozłowska, 2005). O tym zjawisku wspominała również Charlotte Perkins Gilman, która jako pierwsza wykorzystała termin „,androcentryzm”:

Wszystkie schematy obowiązujące w naszym świecie opierają się na tym samym cichym założeniu; mężczyzna uważany jest za wzór człowieka, a kobieta za coś w rodzaju dodatku do niego, czy też podporządkowanego mu pomocnika, przydającego się jedynie do rodzenia dzieci. Kobieta zawsze zajmowała w stosunku do mężczyzny taką pozycję, jaką zajmuje przyimek do rzeczownika. Zawsze była nad nim lub pod nim, przed nim, za nim lub obok niego, zawsze istniała w zależności od mężczyzny -,,Jane, siostra Roberta”, „matka Kowalskiego" - ale w żadnym wypadku sama Jane czy Kowalska (Lipsitz-Bem, 2000). 
Androcentryzm językowy to nic innego, jak brak uwzględnienia kobiet oraz ich doświadczeń w języku (Zamojska, 2012). Jego występowanie jest rezonansem niejednolitego statusu każdej z płci w języku (Karwatowska, Szpyra-Kozłowska, 2005). Dowodem na jego istnienie w polszczyźnie może być zróżnicowany sposób, w jaki traktuje się obie płcie w słownictwie i gramatyce współczesnego języka polskiego. Karwatowska i Szpyra-Kozłowska (2005) przywołują najważniejsze przejawy asymetrii płci w polszczyźnie na takich polach, jak: słowotwórstwo nazwisk i imion oraz rzeczowników pospolitych, leksyka, rzeczowniki męskoosobowe, słownictwo, frazeologia, powiedzenia i przysłowia. Podstawowymi mechanizmami obecnymi w języku androcentrycznym są luki leksykalne, przejawiające się brakiem żeńskich odpowiedników niektórych słów oraz wykorzystywanie form gramatycznych w rodzaju męskim lub męskoosobowym w znaczeniu ogólnym.

\section{Język wrażliwy na płeć i asymetrie rodzajowo-płciowe}

„Asymetria językowa polega na stosowaniu formy męskiej zarówno do określenia osobników płci męskiej, jak i jako formy generycznej, gatunkowej" (Kochman-Haładyj, 2010). Stanowi ona utrwalenie utartych stereotypów płci, które jako psychologiczne konstrukty służą odmiennemu charakteryzowaniu mężczyzn i kobiet (Karwatowska, Szpyra-Kozłowska, 2012). W konsekwencji prowadzi to m.in. do wykluczenia kobiet ze społeczeństwa i ich językowej niewidzialności.

W języku polskim, jak i w wielu innych językach, obowiązuje reguła gramatyczna, która dotyczy tego, że w wypowiedziach odnoszących się do ludzi w ogóle (np. lekarze); osób, których płeć jest nieznana (np. przedstawiciel instytucji) lub w danym kontekście nieistotna (np. typowy pacjent); bądź też do kobiet, dla których zawodu czy aktywności nie istnieją lub nie są używane określenia w formie żeńskiej (np. profesor Wójcik), stosuje się męskie formy leksykalne. Rzeczowniki męskoosobowe w języku polskim są zatem dwuznaczne, mogą odnosić się zarówno do mężczyzn, jak i do kobiet. Żeńskie formy leksykalne odnoszą się zaś wyłącznie do kobiet, nie do „ludzi w ogóle” (Bojarska, 2011). Przykładowo: rzeczownik profesor jest używany w stosunku do obu płci i rzadko kiedy spotyka się formę „profesorka”. Większość rzeczowników rodzaju żeńskiego w języku polskim jest tworzona od rzeczowników rodzaju męskiego, choć istnieją pewne nieliczne wyjątki (np. wdowa $\rightarrow$ wdowiec, gęs $\rightarrow$ gąsior, kaczka $\rightarrow$ kaczor). Zróżnicowanie w kontekście płci dotyczy także form męskoosobowych czasowników w czasie przeszłym. Poprawna forma zdania z czasownikiem „zrobić” brzmi: „Chłopcy 
i dziewczynki zrobili zadanie", natomiast niemęskoosobowa forma czasownika „zrobiły” użyta w tym samym zdaniu traktowana jest jako błąd.

W konsekwencji prowadzi to do licznych absurdów doskonale widocznych także w edukacji. Karwatowska i Szpyra-Kozłowska (2005) wspominają o niewidzialności kobiet w aspekcie językowym. Autorki poddały analizie wybrane podręczniki szkolne, w których w różnym stopniu i nasileniu zarejestrowały występowanie tego zjawiska. Najczęściej jest to widoczne w pojawianiu się rzeczowników $\mathrm{w}$ formie męskoosobowej w stosunku do ogółu lub znaczeniu nazw gatunkowych (np. kolega, nauczyciel, badacz, poeta, artysta) oraz w używaniu męskich form czasowników (np. zrobiłeś, mógłbyś), przymiotników i zaimków (np. jego) nie tylko w poleceniach ćwiczeń, ale też w całych tekstach zawartych w podręcznikach. Pojawiają się również przypadki, w których na męskiego adresata nie wskazują formy poszczególnych wyrazów, ale treść, kontekst tekstu.

Odpowiedzią na widoczne w języku asymetrie płciowe jest przeciwdziałanie językowemu wyłączaniu kobiet. Strategią, która to umożliwia, jest wprowadzenie języka inkluzywnego, równorzędnego dla obu płci - języka wrażliwego na płeć. Jego celem jest zapobieganie dyskryminacji płciowej i promowanie równouprawnienia płci (Zamojska, 2012). Wspiera on równościowe myślenie poprzez uwzględnianie perspektywy zarówno męskiej, jak i żeńskiej, wspomaga dążenia do stanu równego traktowania społecznego, równości praw i obowiązków. Język wrażliwy na płeć można wprowadzać do języka za pomocą różnych strategii, np. równoważącej (używanie par wyrazów o takim samym znaczeniu w wersji żeńskiej i męskiej, łączonych spójnikiem „i"/,lub” albo ukośnikiem, stosowanie zamiennego używania form męskich i żeńskich w toku wypowiedzi) lub neutralizującej (określenia, które w danym języku są wolne od semantycznego znaczenia specyficznego płciowo np. „osoba” i ,jednostka”) (Bojarska, 2011).

Ciekawym przykładem badań potwierdzających jak duże znaczenie ma stosowanie neutralnych lub przeważających dla jednej płci form, są badania opisane przez Bojarską (2011) oraz Karwatowską i Szpyrę-Kozłowską (2005). Bojarska (2011) podsumowuje badania na temat wpływu języka androcentrycznego i inkluzywnego na dostępność umysłową kategorii płci. Wyniki badań ukazały m.in., że pod wpływem gramatycznego rodzaju męskiego używanego w funkcji generycznej uczestnicy badań rysowali przeciętnie mniej postaci kobiecych niż w przypadku języka inkluzywnego. Analiza wyników przeprowadzonych badań pozwoliła na obalenie tezy, że „męskie formy rodzajowe odnoszą się w równym stopniu do mężczyzn, jak i do kobiet" (Bojarska, 2011). Do tezy tej nawiązują również w swoich badaniach Karwatowska i Szpyra-Kozłowska (2005). Jednym z ciekawszych dokonanych przez nie eksperymentów był przeprowadzony na uczniach i uczenni- 
cach z klas IV-VI oraz II gimnazjum (w sumie 96 osób). Zadanie polegało na wysłuchaniu przez uczniów i uczennice dwóch różnych androcentrycznych tekstów czytanych przez nauczycielkę. W kolejnym etapie dzieci poproszono o zakreślenie jednej z wybranych odpowiedzi na pytanie, do kogo ich zdaniem odnosił się tekst: a) chłopców b) dziewczynek c) chłopców i dziewczynek. Z grupy 96 dzieci 94 z nich było zdania, że oba fragmenty odnoszą się tylko do chłopców. W kolejnej części badania na tych samych uczniach autorki zmieniły obydwa fragmenty, zastępując formy męskie w liczbie pojedynczej męskoosobowymi odpowiednikami w liczbie mnogiej np. byłeś mały $\rightarrow$ byliście mali, chodziłeś $\rightarrow$ chodziliście. Następnie grupie uczestników zadano te same pytania, co w poprzednim etapie. Odpowiedzi znacznie różniły się od wcześniej udzielonych. Według 90 dzieci zmienione wersje odnosiły się tak samo do chłopców, jak i do dziewcząt, a zgodnie z oceną tylko 6 uczniów wyłącznie do chłopców.

W świetle przytoczonych badań oraz spostrzeżeń autorów i autorek nie ulega wątpliwości, z jak dużą wrażliwością językową powinny być traktowane komunikaty przekazywane nie tylko najmłodszym, ale też dorosłym. Seksizm językowy, czasem nieświadomie wpajany dzieciom od najmłodszych lat, znacząco wpływa na kształtowanie się wartości, przekonań i postaw w społeczeństwie, często krzywdząc jedną z płci. W tym miejscu należy zaznaczyć, że język odgrywa zasadniczą rolę w postrzeganiu świata. Wzmacnianie androcentrycznego oglądu świata poprzez wyrażanie sprzeciwu wobec języka wrażliwego na płeć tylko pogłębia stereotypowe postrzeganie kobiet i mężczyzn oraz nierówności płciowe w przestrzeni prywatnej i publicznej.

\section{Opór wobec języka wrażliwego na płeć}

W języku polskim silnie zakorzeniony jest androcentryzm językowy. Mimo że reguły słowotwórstwa pozwalają na utworzenie żeńskich odpowiedników nazw zawodów, użytkownicy języka niechętnie korzystają z tej możliwości. Pauwels jako główne przyczyny negacji i sprzeciwu wobec języka wrażliwego na płeć wymienia: naruszenie tradycji, przyzwyczajeń językowych, przeciwdziałanie puryzmowi językowemu, ośmieszające brzmienie języka, negacja istnienia seksizmu językowego, bagatelizowanie problemu lub nieuznawanie go, dyskredytowanie wyników badań i niekompetencja reformatorów języka, brak akceptacji społecznej dla nowo wprowadzonych zmian, trudności we wprowadzeniu modyfikacji w skomplikowaną strukturę gramatyczną języka (Pauwels, 1998, za: Karwatowska, Szpyra-Kozłowska, 2005). 
Większość z wymienionych argumentów okazuje się być łatwa do obalenia. Adamowicz (2019) za nietrafne uznaje spostrzeżenie, że używanie feminatywów jest niezgodne $\mathrm{z}$ tradycjami kultywowanymi w języku polskim. Dostępnych jest wiele zarchiwizowanych materiałów historycznych obalających tezę głoszącą, że używanie feminatywów jest odstępstwem od tradycji języka. Wtorkowska (2019) za jedną z przyczyn blokady derywacji nazw żeńskich przytacza chęć uniknięcia homonimii. Przykładem homonimu jest słowo „pilotka” - oznaczające zarówno kobietę kierującą samolotem, jak i charakterystyczny rodzaj czapki. Jednakże używanie słowa „pilotka” zamiast „pilot” w stosunku do kobiety nie powinno być bardziej kłopotliwe niż posługiwanie się słowem „pilot” w znaczeniu osoba, nie urządzenie sterujące. Warto zauważyć, że w przypadku homonimii (nie tylko w języku polskim, ale też w innych, np. angielskim) zawsze decyduje kontekst. To właśnie on sprawia, że wiemy, co rozmówca miał na myśli i tym samym minimalizujemy szanse na nieporozumienie.

Pojawiają się również głosy, że niektóre z nazw żeńskich odczuwane są jako pejoratywne i brzmią prześmiewczo, co jednocześnie zniechęca do ich używania, np. cukierniczka, profesorka. Używanie sufiksu -k(a) wskazuje na małość desygnatu, co w odbiorze użytkowników języka może sprawić, że słowo zostanie uznane za takie o obniżonej wadze, np. lampka, rączka, szafka (Wtorkowska, 2019). Kolejną pobudką, która może stać za blokadą derywacji, jest trudność $\mathrm{w}$ wymowie niektórych nazw żeńskich spowodowana powstawaniem zbitek spółgłoskowych. Feminatywa utworzone od słowa chirurg, architekt, pediatra za pomocą sufiksu -k(a) brzmiałyby: chirurżka, architektka, pediatrka. Ze względu na nagromadzenie spółgłosek obok siebie wyrazy te nie są łatwe do wymówienia (Wtorkowska, 2019). Język polski zawiera jednak w sobie wiele słów o podobnym lub nawet wyższym poziomie trudności artykulacyjnych. Rada Języka Polskiego w swoim stanowisku podaje przykłady słów, np. bezwzględny, zmarszczka, które z powodzeniem funkcjonują w codziennej mowie wielu Polaków, mimo że zawierają aż 5 stłoczonych spółgłosek (wymienione feminatywa mają tylko 3).

Same kobiety często unikają używania w stosunku do siebie żeńskich nazw $z$ uwagi na to, iż niosą one za sobą niższy prestiż niż nazwy męskie. Według niektórych użytkowniczek języka nazwy męskie brzmią bardziej dostojnie i wpływowo, a dodatkowo skłaniają odbiorców do większego poszanowania. Łaziński (2006) jednej z głównych przyczyn blokady derywacji nazw żeńskich dopatruje się w funkcji tytularnej rzeczowników męskoosobowych. W języku polskim rzeczowniki tytularne, mimo że posiadają regularne, powszechnie używane feminatywa, 
w połączeniu z tytułem „pani” pozostają w rodzaju męskim (np. doktor, mecenas, profesor). Zbędność użycia nazwy żeńskiej (w tym przypadku) argumentowana jest jednoznacznym wskazaniem płci przez rzeczownik „pani” (Wtorkowska, 2019). Jadacka podkreśla, że:

W postaci żeńskiej pozostały już tylko nazwy zawodów tradycyjnie wykonywanych przez kobiety, np. aktorka, malarka, nauczycielka, pisarka albo uchodzących za mało atrakcyjne, o niewysokiej randze społecznej, np. ekspedientka, fryzjerka, sprzątaczka. W dzisiejszej polszczyźnie nie ma żadnej nazwy prestiżowego stanowiska, stopnia czy tytułu naukowego, która miałaby żeńską formę słowotwórczą (Jadacka, 2012).

Wskazuje to na uprzywilejowanie rodzaju męskiego i często prowadzi do absurdalnych sytuacji językowych. Łaziński (2006) podaje przykład słowa „nauczyciel”, od którego bez większego problemu derywowana jest nazwa żeńska nauczycielka. Sytuacja zmienia się w przypadku stanowiska bardziej prestiżowego i o wyższym statusie społecznym - nauczyciel akademicki. W konsekwencji w 1990 roku w Ustawie o szkolnictwie wyższym zamieszczono zapis:

Nauczyciela akademickiego w ciąży lub wychowującego dziecko w wieku do jednego roku nie można zatrudniać w godzinach ponadwymiarowych bez jego zgody (Ustawa $\mathrm{z}$ dnia 12 września 1990 r. o szkolnictwie wyższym, art. 123).

Mimo że ustawa ta została uchylona, w ustawie Prawo o szkolnictwie wyższym i nauce z dnia 20 lipca 2018 r. (tekst ujednolicony - Dz. U. z 2021 r. poz. 478) zapis wygląda porównywalnie. Znów pod uwagę nie wzięto odpowiedniejszej formy nauczycielka akademicka, która lepiej pasowałaby do kontekstu zdania.

Karwatowska i Szpyra-Kozłowska (2005) również zwracają uwagę na widoczną asymetrię między występowaniem form żeńskich i męskich. Autorki podają przykład odrębnych męskich nazw zawodów typowo kobiecych, jak np. kosmetyczka - kosmetolog, przedszkolanka - wychowawca przedszkolny.

Można by uznać, że nazewnictwo osób wykonujących dany zawód związane jest z tym, która z płci tradycyjnie go wykonywała lub gdzie jedna z płci jest dominująca, np. niania - zawód typowo kobiecy, a więc brak męskiego odpowiednika, górnik - profesja podejmowana przeważnie przez mężczyzn, stąd brak w użyciu żeńskiej formy. Jednak idąc tym tropem, prawdziwe byłoby stwierdzenie, że logopeda jest zawodem pełnionym głównie przez mężczyzn (Łaziński, 2006). Jako studentka logopedii mogę zauważyć, że mężczyźni w tym fachu są zdecydowaną mniejszością. 


\section{Analiza wybranych dokumentów uniwersyłeckich w kontekście języka wrażliwego na płeć}

Sposób pisania oficjalnych dokumentów szczególnie uwydatnia asymetryczność rodzajowo-płciową występującą w języku polskim i podkreśla zjawisko językowej niewidzialności kobiet. Rodzaj męski traktowany jest jako rodzaj uniwersalny dla wszystkich użytkowników języka, również osób płci żeńskiej. Uniwersalizacja męskich form jednoznacznie manifestuje obecny w języku androcentryzm, a ponadczasowe okazuje się twierdzenie: „Wszelkie prawidła, maksymy, ustawy, artykuły praw, utrzymane w tonie ogólnym i stosujące się do wszystkich mieszkańców redagowane są w rodzaju męskim" (J. Baudouin de Courtenay, za: Karwatowska, Szpyra-Kozłowska, 2005).

Na potrzeby tego tekstu poddałam analizie dwa dokumenty, funkcjonujące w oficjalnym obiegu w UAM w Poznaniu.

Regulamin studiów Uniwersytetu im. Adama Mickiewicza² redagowany jest w taki sposób, jakby dotyczył wyłącznie płci męskiej. Już w pierwszym punkcie przykuwa uwagę zapis: „prawa i obowiązki studenta”. Podobne formy występują również w kolejnych punktach regulaminu, np. „Prawa studenta nabywa się z chwilą złożenia ślubowania (...)”, „(...) student złożył wniosek w swojej sprawie (...)”, „(...) student przedkłada dziekanowi (...)”, „(..) wniosek studenta (...)”, „(...) student otrzymał uprawnienie do nieuczestniczenia w zajęciach (...)" (Regulamin...). Mimo że rzeczownik „student” $w$ języku polskim regularnie występuje (i jest używany) również w formie żeńskiej - studentka, w dokumencie użyty jest praktycznie wyłącznie w formie męskiej (Od 1894 na uczelniach w Polsce spotkać można również studentki, Sikora, 2007). Podobnie wygląda sytuacja w przypadku osoby rektora, dziekana, ale także innych stanowisk obejmowanych na uczelni: „Rektor Uniwersytetu może ustanowić (...)”, „Dziekan może zawiesić zajęcia (...)”, „(...) opiekuna naukowego, którym może być profesor albo doktor habilitowany”, „Dziekan wydziału prowadzącego dane zajęcia w porozumieniu z prowadzącym zajęcia lub egzaminatorem (...)", „(...) nauczyciela akademickiego wydziału lub przedstawiciela samorządu studenckiego w charakterze obserwatora (...)" (Regulamin...).

W analizowanym dokumencie występują następujące rzeczowniki męskoosobowe: opiekun naukowy, profesor, doktor, dziekan, egzaminator, specjalista, nauczyciel akademicki, przedstawiciel samorządu, obserwator, recenzent, promotor, przewodniczący komisji, student, rektor, dyrektor, opiekun naukowy. Są one w tre-

\footnotetext{
2 Por. Regulamin studiów Uniwersytetu im. Adama Mickiewicza w Poznaniu (2019), https://amu. edu.pl/studenci/przewodnik_studenta/regulamin-studiow, dostęp: 1.03.2020.
} 
ści regulaminu traktowane jako prymarne, nie występują w formach żeńskich bez względu na to, czy w istnieją dla nich odpowiedniki żeńskie.

Derywat „studentka” występuje w regulaminie w bardzo niewielkim zakresie. Znaleźć można go w paragrafach 14 i 44, które dotyczą kwestii związanych z ciążą i rodzicielstwem. W tych paragrafach możliwa staje się symetryczność płci pod względem językowym.

$\$ 14$ Studentce w ciąży i studentowi będącemu rodzicem dziekan udziela zgody na odbywanie studiów stacjonarnych według indywidualnej organizacji studiów zgodnie z zasadami określonymi w $\$ 13$ ust. $2-4$.

$\$ 44$

(...)

3. Urlopu, o którym mowa w ust. 1, dla:

1) studentki w ciąży udziela się na okres do dnia urodzenia dziecka,

2) studenta będącego rodzicem udziela się na okres do 1 roku (Regulamin...).

Moim zdaniem jednak zapis ten jest nieodpowiednio zredagowany. Pierwsza część trzeciego podpunktu ewidentnie odnosi się do kobiet. W drugiej części natomiast pojawia się słowo „student”, które (w zestawieniu ze słowem „studentka” w punkcie poprzednim) sprawia wrażenie jakby dotyczyło wyłącznie osób płci męskiej.

W regulaminie pojawiają się także nieliczne zwroty o neutralnym wydźwięku dla obu płci, np. „(...) osoby prowadzącej zajęcia (...)”. „Osoba”, mimo żeńskiego rodzaju gramatycznego, nie wywołuje wrażenia słowa, które bardziej odnosi się do kobiet niż do mężczyzn.

Kolejnym poddanym analizie dokumentem UAM jest Przewodnik studenta, Pedagogika - Pedagogika specjalna 2016/2017³. Przewodnik, mimo wyłącznie męskiej formy słowa "student” $\mathrm{w}$ tytule, rozpoczyna się zwrotem skierowanym do osób obojga płci: „Szanowna Studentko, Szanowny Studencie” (Przewodnik...). Jednakże w dalszej części tekstu, podobnie jak w przypadku wspomnianego Regulaminu studiów Uniwersytetu im. Adama Mickiewicza w Poznaniu, nadrzędnie nad formami żeńskimi występują formy męskie. W Przewodniku... osoba studiująca nazywana jest wyłącznie studentem: „wyniki studenta w nauce”, „(...) student może załatwić sprawy związane z tokiem studiów”, „(...) kontakt między studentami” (Przewodnik...). Prócz rzeczowników liczby pojedynczej rodzaju męskiego

${ }^{3}$ Por. Przewodnik studenta, Pedagogika - Pedagogika specjalna 2016/2017, https://docplayer.pl/42161769-Przewodnik-studenta-pedagogika-pedagogika-specjalna-rok-akademicki-2016-2017-uniwersytet-im-adama-mickiewicza-w-poznaniu.html, dostęp: 1.04.2020. 
oraz rzeczowników liczby mnogiej rodzaju niemęskoosobowego w Przewodni$k u$... występują również inne części mowy - m.in. czasowniki czasu przeszłego w rodzaju męskim, np. „W wykazie zaliczeń odnotowuje się wyniki studenta w nauce, podając listę zajęć, na które uczęszczał student (...)" (Przewodnik...) oraz zaimki rodzaju męskiego, np. „Każdy student ma obowiązek (...)” (Przewodnik...). W dokumencie, prócz zwrotu we wstępie, próżno szukać śladu żeńskiego odpowiednika słowa „student”, regularnie przecież używanego przez osoby posługujące się językiem polskim. Nawet w harmonogramie roku akademickiego zawartym w Przewodniku... uwzględniony jest „Dzień Studenta I roku” (Przewodnik...), a nie np. „Dzień Studenta i Studentki I roku”. Maskulinizacja dotyczy, tak jak i w regulaminie studiów UAM, również nazw osób pracujących na uczelni: wykładowca, opiekun roku, koordynator, dziekan, prodziekan, rektor, asystent, konsultant, pracownik i inne. W części dotyczącej dziekanatu do spraw toku studiów zamieszczona jest tabela $\mathrm{z}$ nazwiskami pracowników obsługujących dane specjalności i kierunki. Pod nagłówkiem tabeli („Pracownik”) umieszczonych jest 6 imion i nazwisk należących wyłącznie do kobiet. Wydaje się zatem, iż w nagłówku bardziej pasowałby żeński odpowiednik „Pracownice”. Sytuacja wygląda podobnie w przypadku wyszczególniania funkcji pełnionych przez personel uniwersytetu. Ich forma jest nadal męska, nawet w przypadku zestawienia z żeńskim imieniem i nazwiskiem (nawet pomimo istnienia żeńskiego odpowiednika), np. „Kierownik specj. prof. Ewa...”, „koordynator dr Maria ...., „Opiekun: mgr Anna ....”, „Prezes Agnieszka ...”4 (Przewodnik...). W sprawie innych osób związanych z uniwersytetem także dominują formy męskie, np. „Stały kontakt ze starostą roku”, „(...) w czasie dyżurów wolontariuszy na każdego gościa (...)”, „Uczestnikiem Programu może zostać" (Przewodnik...). Ponadto w Przewodniku... występują całe fragmenty, które sugerują męskiego odbiorcę:

Jeśli jesteś studentem I roku II stopnia Twoja „przygoda” z praktykami zacznie się w semestrze letnim pierwszego roku. Wykorzystaj ten czas na sprawdzenie czy w czasie studiów I stopnia uzyskałeś przygotowanie pedagogiczne.

W analizowanym dokumencie pojawiają się jednak także zwroty neutralne, w równym stopniu odnoszące się do płci męskiej i żeńskiej, np. „Osoby niespełniające tego warunku nie będą przyjmowane" (Przewodnik...).

Fakt dominacji męskich form gramatycznych $\mathrm{w}$ obydwu rozpatrywanych przeze mnie dokumentach wynika przede wszystkim $\mathrm{z}$ ich generycznego cha-

${ }^{4} \mathrm{~W}$ artykule wymienione osoby poddano anonimizacji, pozostawiając tylko imiona, choć w Przewodniku... figurują w pełnej formie, także z nazwiskami. 
rakteru. Przywilej generyczności nazw męskich nie do końca moim zdaniem się sprawdza i nie jest synonimem neutralności, a raczej podkreśleniem męskiej dominacji językowej. Uważam, że nazwy te są w odbiorze bardziej męskie niż żeńskie i, jak wykazały np. Karwatowska i Szpyra-Kozłowska w swoich publikacjach (2005, 2012), o wiele częściej są one w ten sposób postrzegane. Sztywne ramy językowego postępowania ustalone dawno temu przestają być w obecnych czasach aktualne ze względu na zachodzące w języku i społeczeństwie zmiany. Uważam, że język powinien być elastyczny i odpowiadać społecznym potrzebom. Istnieje wiele metod, które pozwolą na wprowadzenie do języka większej symetrii. Wśród najważniejszych mechanizmów niwelujących androcentryzm językowy Duda (2016) wymienia: stosowanie nazw żeńskich, męskich i bezosobowych na zmianę, słowotwórstwo za pomocą sufiksów -ka, -ina, wykorzystywanie słów o neutralnym wydźwięku (np. klientela zamiast klienci), unikanie użycia męskich zaimków i zamienianie ich na bardziej ogólne (np. każdy biorący udział, wszyscy biorący udział), stosowanie dwóch rzeczowników w miejsce liczby mnogiej (np. studenci i studentki, lekarze i lekarki), używanie splittingu.

O wykorzystaniu splittingu pisze Woźniak (2014), definiując to określenie jako wskazujące na jednoczesne użycie formy męskiej i żeńskiej, aby podkreślić odniesienie do obydwu płci. Autorka zauważa, że już 100 lat temu strategia ta była stosowana w języku (być może nawet śmielej niż obecnie). Wadą splittingu jest jednak z pewnością odejście od ekonomiczności języka, jednak, jak podkreśla Duda (2016), należy zastanowić się, co jest ważniejsze - językowa ekonomia czy podmiotowe traktowanie innych.

\section{Zakończenie}

Nie ulega wątpliwości, że język ma znaczny wpływ na postrzeganie świata przez jego użytkowników. To, w jaki sposób (i czy w ogóle) nazwiemy dane zjawisko, też zależy od możliwości języka (i chęci jego użytkowników). Może on służyć za narzędzie utrwalające zwyczajowe stereotypy lub jako narzędzie zrównujące czy chroniące grupy poddawane wpływowi stereotypów (np. kobiety).

W mojej opinii kwestia asymetrii płci w języku nie powinna być bagatelizowana. Język polski pełen jest wyrażeń pejoratywnych, określeń, za pomocą których jednostki mogą zostać postawione w negatywnym świetle. Nierówne traktowanie płci zakodowane w języku, jak wykazały m.in. Karwatowska i Szpyra-Kozłowska (2005), może mieć wielce niekorzystny wpływ na samoocenę jednostek oraz ich pozycję społeczną. 
By zniwelować owe nierówności, trzeba by przede wszystkim większej świadomości dotyczącej omawianych przeze mnie zjawisk, szczególnie wśród osób niezwiązanych z lingwistyką - wiele osób wyraża swoje myśli w sposób intuicyjny, taki, jaki jest im najbardziej znany (czyli ten androcentryczny, którego uczą się już od dziecka). Wydaje się, że konieczne byłyby zmiany oparte na przeobrażeniach społecznych, zmianie sposobu myślenia o płci i zjawisku równości płci. Nawet usilne wprowadzanie zmian nic nie da, jeśli nastawienie użytkowników/ użytkowniczek języka się nie zmieni, gdyż - jak pisze Simone de Beauvoir (2017): „Spór będzie trwał dopóty, dopóki mężczyźni i kobiety nie uznają się wzajem za równych (...)".

Uważam, że kwestia języka wrażliwego na płeć zarówno w języku potocznym, jak i oficjalnym jest niezmiernie ważna i zdecydowanie nie powinno się jej bagatelizować. Powszechne stosowanie form żeńskich przez użytkowniczki i użytkowników języka zapewne utorowałoby drogę do stłumienia ciągle żywych w społeczeństwie stereotypów i uprzedzeń. Pozwoliłoby także na postawienie znaku równości między kobietami i mężczyznami nie tylko w języku, ale też w kulturze.

\section{Bibliografia}

Adamowicz A. (2019), Społeczne i językowe potencjały kontrhegemoniczne, Avant, 11(3).

Beauvoir S. de (2017), Druga płeć, Warszawa.

Bojarska K. (2011), Wpływ androcentrycznych i inkluzywnych płciowo konstrukcji językowych na skojarzenia z płcią, Studia Psychologiczne, t. 49, z. 2.

Buttler D., Kurkowska H., Satkiewicz H. (2008), Kultura języka polskiego. Zagadnienia poprawności gramatycznej, Warszawa.

Duda M. (2016), Płeć języka polskiego, [w:] I. Chmura-Rutkowska, M. Duda, M. Mazurek, A. Sołtysiak-Łuczak (red.), Gender w podręcznikach. Projekt badawczy. Raport, t. 1, Warszawa.

Filipiak E. (2008), Człowiek - język - rzeczywistość (w kontekście pytań o efektywną edukację językową w szkole), Forum Dydaktyczne: przeszłość, teraźniejszość, przyszłość, nr 3/4.

Glen F., Hurrell K. (2012), Technical note: Measuring Gender Identity, Equality and Human Rights Commission https://www.equalityhumanrights.com/sites/default/files/technical_note_final.pdf, dostęp: 1.05.2020.

Gontarczyk E. (1995), Kobiecość i męskość jako kategorie społeczno-kulturowe w studiach feministycznych: perspektywa socjologiczno-pedagogiczna, Poznań.

Jadacka H. (2005), Kultura języka polskiego. Fleksja, słowotwórstwo, składnia, Warszawa.

Karwatowska M., Szpyra-Kozłowska J. (2005), Lingwistyka płci: ona i on w języku polskim, Lublin.

Karwatowska M., Szpyra-Kozłowska J. (red.) (2012), Oblicza płci: język, kultura, edukacja, Lublin.

Kawiorski S. (2014), Uwagi o przekładzie językowym, Podkarpackie Studia Biblioteczne, nr 3.

Kierownik: czasopismo Kat. Związku Młodzieży Żeńskiej i Kat. Związku Młodzieży Męskiej (1935), Rocznik XIV, nr 12, https://www.wbc.poznan.pl/dlibra/publication/410990/edition/348771/ content, dostęp: 1.05.2020. 
Kochman-Haładyj B. (2010), Seksizm językowy jako jeden z mechanizmów dyskryminacji kobiet, [w:] G.A. Kleparski, R. Kiełtyka (red.), Podkarpackie Forum Filologiczne, Jarosław.

Lipsitz-Bem S. (2000), Męskość, kobiecość: O różnicach wynikających z płci, przeł. S. Pikiel, Gdańsk.

Łaziński M. (2006), O panach i paniach: polskie rzeczowniki tytularne i ich asymetria rodzajowo-ptciowa, Warszawa.

Przewodnik studenta, Pedagogika - Pedagogika specjalna 2016/2017, https://docplayer.pl/42161769Przewodnik-studenta-pedagogika-pedagogika-specjalna- rok-akademicki-2016-2017-uniwersytet-im-adama- mickiewicza-w-poznaniu.html, dostęp: 1.04.2020.

Rada Języka Polskiego (2012), Stanowisko Rady Języka Polskiego w sprawie żeńskich form nazw zawodów i tytułów, XXXVII posiedzenie plenarne, Prezydium PAN, http://www.rjp.pan.pl/index. php?option $=$ com_ content\&view $=$ article\&id=1359:stanowisko - rady-jzyka-polskiego $-\mathrm{w}-$ spra wie-eskich-form- nazw-zawodow-i-tytuow, dostęp: 1.04.2020.

Rada Języka Polskiego (2019), Stanowisko Rady Języka Polskiego przy Prezydium PAN w sprawie żeńskich form nazw zawodów i tytułów przyjęte na posiedzeniu plenarnym Rady 25 listopada 2019 r., http://www.rjp.pan.pl/index.php?option=com_content\& view=article\&id=1861:stanowisko-rjp-w-sprawie- zenskich-form-nazw-zawodow-i-tytulow\&catid=98\&Itemid=58, dostęp: 1.04.2020.

Regulamin studiów Uniwersytetu im. Adama Mickiewicza w Poznaniu (2019), https://amu.edu.pl/studenci/przewodnik_studenta/regulamin-studiow, dostęp: 1.03.2020.

Richards Ch. i in. (2016), Non-Binary or Genderqueer Genders, International Review of Psychiatry, $48(1)$.

Sapir E. (1978), Kultura, język, osobowość, Warszawa.

Siatkowska E. (2012), Konkurencja czynników zewnętrznych i wewnętrznych w tworzeniu polskich i czeskich feminatywów (przyczynek do badań nad ptcia kulturowa), [w:] M. Karwatowska, J. Szpyra-Kozłowska (red.), Oblicza płci. Język, kultura, edukacja, Lublin.

Sikora K. (2007), Pierwsze kobiety na Uniwersytecie Jagiellońskim, Annales Universitatis Paedagogicae Cracoviensis. Studia Politologica, 3.

Skalski D. (2015), Krytyczno-konstruktywistyczna koncepcja socjalizacji ruchowej, Rocznik Nauko$w y, 113$.

Wittgenstein L. (1970), Traktat logiczno-filozoficzny, przeł. B. Wolniewicz, Kraków.

Woźniak E. (2014), Język a emancypacja, feminizm, gender, Rozprawy Komisji Językowej, 60.

Wtorkowska M. (2019), O żeńskich formach nazw zawodów, tytułów i stanowisk w języku polskim, Slavistična revija, 67(2).

Zamojska E. (2010), Równość w kontekstach edukacyjnych: wybrane aspekty równości w polskich i czeskich podręcznikach szkolnych, Poznań.

Zamojska E. (2012), „Murzynek Bambo wiecznie żywy!”. Rzeczywistość politycznej poprawności w podręcznikach szkolnych, Przegląd Pedagogiczny, nr 2.

Ziemińska R. (2017), „Uwikłani w płeć” - od wytwarzania i reprodukowania męskości po formy przekraczania płci: Osoby interpłciowe: praktyki medyczne, ruch społeczny i problem trzeciej kategorii płciowej, Miscellanea Anthropologica et Sociologica (MAeS), 18(2). 